\title{
Benign Obstetric History in Women with Sickle-cell Anaemia Associated with $\alpha$-Thalassaemia
}

\author{
A. vAN ENK, A. LANG, J. M. WHITE, H. LEHMANN
}

British Medical fournal, 1972, 4, 524-526

\section{Summary}

Two Ghanaian women with sickle-cell anaemia and $\alpha$-thalassaemia were found to have an unusually benign obstetric history. In addition to two factors present which are known to moderate the clinical course of sickle-cell anaemia, good socioeconomic status and a relatively high $\mathrm{Hb}$ F level, it is suggested that $\alpha$-thalassaemia may act among other things by lowering the haemoglobin concentration in the red cells and thereby lowering their tendency to sickle in vivo.

\section{Introduction}

Homozygous sickle-cell disease, "sickle-cell anaemia," is distinct from other sickle-cell syndromes and results from all the $\beta$-chains of adult haemoglobin $\left(\alpha_{2} \beta_{2}\right)$ being $\beta^{S}$-chains with the amino-acid substitution at $\beta_{6}$ (A3) Glu-Val. Sickle-cell anaemia is generally a severe condition with high morbidity and mortality rates. The severity appears to be influenced, however, by the social and economic environment of the affected patients. For instance, it is greater in Africa than in the West Indies and in North America but, nevertheless, survival of patients to the third decade is well recognized in all three, and a series of such patients seen at the Sickle-cell Anaemia Clinic, Accra, has been described by Konotey-Ahulu (1971). Although it was usually regarded as rare, Serjeant et al. (1968) were able to find 60 "benign" cases in Jamaica and review other reports from the literature. They concluded that the apparent rarity of this type of sickle-cell anaemia might be explained by the lack of clinical presentation.

The milder type may reflect part of the general spectrum of sickle-cell anaemia or result from some specific additional factors. The most common is an increased level of $\mathrm{Hb} F$ (Charache and Conley, 1964), especially above $10 \%$, another is the presence of an $\alpha$-chain mutant-Hb Memphis $\alpha 23$ (B4) Glu-Gln (Kraus et al., 1966). It also appears that in that type of sickle-cell thalassaemia in which formation of the normal adult haemoglobin is completely suppressed a more benign disease results; yet although this is not homozygous sickle-cell anaemia the only chains synthesized from the $\beta$-chain loci are $\beta^{S}$-chains (Serjeant et al., 1973).

Weatherall et al. (1969) suggested that the genotype $\mathrm{Hb} \mathrm{S/ \alpha -}$ thalassaemia might also modify the clinical severity. In a family in which both $\mathrm{Hb} S$ and $\alpha$-thalassaemia were segregating, a child aged 30 months was homozygous for $\mathrm{Hb} \mathrm{S}$ and also had $\alpha$-thalassaemia. The haemoglobin pattern was $\mathrm{Hb} S 46 \%$, $\mathrm{Hb}$ F $44 \%$, and $\mathrm{Hb}$ Bart's $\left(\gamma_{4}\right) 1 \%$. At the time of the investigation the child had had none of the clinical symptoms associated with sickle-cell disease in infants. However, since the $\mathrm{Hb} \mathrm{F}$ level was so high it is difficult to be certain whether the presence of $\alpha$-thalassaemia had any modifying effect on the disease.

Agogo Hospital (Presbyterian Church of Ghana), Agogo AshantiAkim, Ghang

A. VAN ENK, M.D., Physician (Present address: Department of Obstetrics and Gynaecology, Academy Ziekenhuis, Vrije Universiteit, De Boelelaan 1117, Amsterdam, Holland)

Medical Research Council Abnormal Haemoglobin Unit, University Department of Biochemistry, Cambridge

A. LANG, PH.D., Member of Scientific Staff

J. M. WHITE, M.B., CH.B., Attached Worker

H. LEHMANN, M.D., F.R.C.P., F.R.S., Honorary Director
We report here the case histories and investigations of two patients with homozygous sickle-cell disease with interacting $\alpha$-thalassaemia. The condition of the patients can be classified as "benign" not only because both were aged 32 years but more especially because both had had multiple uncomplicated pregnancies.

\section{Methods}

Routine haematological indices were measured by using standard methods (Dacie and Lewis, 1968). The proportions of $\mathrm{Hb} \mathrm{S}, \mathrm{F}$, and $\mathrm{A}_{2}$ were measured by chromatography on DEAESephadex (Huisman and Dozy, 1965), by electrophoresis on cellulose acetate (Marengo-Rowe, 1965), and by alkali resistance (Betke et al., 1959). The distribution of the $\mathrm{Hb} F$ in the red cells was determined by the acid elution technique (Nierhaus and Betke, 1968). The presence of $\mathrm{Hb}$ Bart's was detected by starch gel electrophoresis at pH 7.7 (Huehns et al., 1960), and intracellular inclusions were detected after incubating the red cells with brilliant cresyl blue for 60 minutes at $37^{\circ} \mathrm{C}$.

Biosynthetic Studies.-Aliquots $(5 \mathrm{ml})$ of incubation mixture were prepared according to the method of Lingrel and Borsook (1963) containing all the essential amino-acids except leucine, as well as glutamine, glucose, ferrous ammonium sulphate, penicillin, and streptomycin. A total of $100 \mu \mathrm{Ci}$ of ${ }^{3} \mathrm{H}$-leucine were added to the sample, which was frozen and transported on dry ice to Ghana. About 1-2 $\mathrm{ml}$ of bone marrow aspirate from each patient were added to $10 \mathrm{ml}$ of saline-heparin at $4^{\circ} \mathrm{C}$, well agitated, and the cells washed three times with saline. The whole of the cell sample was added to the incubation mixture and incubated at $37^{\circ} \mathrm{C}$ for 1 hour. Globin synthesis was terminated by adding the whole cell sample to excess of ice-cold saline. The cells were washed three times with saline and then transported to Cambridge. The globin from the whole cell sample was precipitated by adding to it acid acetone at $20^{\circ} \mathrm{C}$ and the $\alpha$ - and $\beta$-chains were isolated by chromatography in columns of C.M.C. using 8-molar urea phosphate buffers (Clegg et al., 1966). The whole of each chain was collected and dialysed against 5:1 of $0.5 \%$ formic acid for 48 hours, after which the specific activities and the total ${ }^{3} \mathrm{H}$-leucine incorporated into each chain was determined.

\section{Case 1}

A woman aged 32 years had a diagnosis of sickle-cell anaemia first made at the age of 16 years at the Agogo Hospital, where she was admitted with periostitis of the right leg. She gave a past history of recurrent attacks of neck and back pains. Between the ages of 16 and 31 she was in hospital on only three occasions because of symptoms which could be attributable to sickle-cell crises-namely, severe pains in her back and legs. The rest of her clinical history concerned her pregnancies. In 1958 she had a uterine curettage for a missed abortion. In 1959 she was delivered of a stillborn fetus after 28 weeks of pregnancy. No cause for this was found. Between 1960 and 1972 she had six successful pregnancies. All of the deliveries were at home (on advice of a native healer), and none of the pregnancies were associated with any complications. Her haemoglobin level always varied between $7 \cdot 5-10.5 \mathrm{~g} / 100 \mathrm{ml}$.

At the present examination she was $5 \mathrm{ft} 4$ in $(162 \mathrm{~cm})$ in height and had slight frontal bossing and gnathopathy. She was icteric, and the liver extended three finger-breadths below the costal margin. The spleen was impalpable. Haemoglobin electrophoresis showed 
TABLE I-Haematological Findings in Study Patients and their Parents

\begin{tabular}{|c|c|c|c|c|c|c|c|c|c|}
\hline \multirow{2}{*}{\multicolumn{2}{|c|}{ Patient }} & \multirow{2}{*}{$\begin{array}{l}\text { Haemoglobin } \\
(\mathrm{g} / 100 \mathrm{ml})\end{array}$} & \multirow{2}{*}{$\begin{array}{c}\text { Mean Corpuscular } \\
\text { Haemoglobin } \\
(\%)\end{array}$} & \multirow{2}{*}{$\begin{array}{c}\text { Mean Corpuscular } \\
\text { Haemoglobin } \\
\text { Concentration } \\
(\%) \\
\end{array}$} & \multirow{2}{*}{$\underset{(\mu \mathrm{g} / 100 \mathrm{ml})}{\text { Serum } \mathrm{Fe}}$} & \multicolumn{4}{|c|}{ Haemoglobin (\%) } \\
\hline & & & & & & $\mathbf{S}$ & F & $\mathbf{A}_{2}$ & Bart's \\
\hline $\begin{array}{l}\text { Case 1 } \\
\text { Father } \\
\text { Mother } \\
\text { Case 2 } \\
\text { Mother }\end{array}$ & $\begin{array}{l}\cdots \\
\cdots \\
\cdots \\
\cdots\end{array}$ & $\begin{array}{r}8 \cdot 8 \\
14 \cdot 6 \\
11 \cdot 9 \\
8 \cdot 2 \\
11 \cdot 7\end{array}$ & $\begin{array}{l}19 \\
30 \\
32 \\
26 \\
29 \cdot 2\end{array}$ & $\begin{array}{l}29 \cdot 3 \\
30 \cdot 4 \\
32 \\
27 \cdot 0 \\
30 \cdot 8\end{array}$ & $\begin{array}{l}18 \\
15\end{array}$ & $\begin{array}{l}84 \cdot 2 \\
30 \cdot 0 \\
30 \cdot 7 \\
82 \cdot 2 \\
32 \cdot 5\end{array}$ & $\begin{array}{r}12.4 \\
0.7 \\
1.2 \\
14 \cdot 6 \\
1.3\end{array}$ & $\begin{array}{l}3 \cdot 1 \\
3 \cdot 2 \\
3 \cdot 7 \\
3 \cdot 2 \\
4 \cdot 0\end{array}$ & $\begin{array}{l}\text { Trace } \\
\text { Trace } \\
-\end{array}$ \\
\hline
\end{tabular}

In Case 2 the father was not available for investigation.

Hbs $S, F$, and $A_{3}$, and a trace of a fast-moving haemoglobin in the position of $\mathrm{Hb}$ Bart's. The $\mathrm{Hb} \mathrm{F}$ was heterogeneously distributed among the red cells, some of which were found to contain small inclusion bodies. She was also iron deficient; serum iron $18 \mu / 100 \mathrm{ml}$. Both her parents were alive and sickle-cell trait carriers; her husband and one brother had no $\mathrm{Hb} \mathrm{S}$. All children had $\mathrm{Hb} \mathrm{S}$, and the one born in 1972 had about $1 \% \mathrm{Hb}$ Bart's in its cord blood.

\section{Case 2}

A woman aged 32 years had symptoms which could be attributable to sickle-cell disease-that is, recurrent attacks of pain in limbs and chest, which began at the age of 15 . The diagnosis of sickle-cell anaemia was not made until one year later when she was admitted to the Agogo Hospital with severe anaemia (haemoglobin $3.3 \mathrm{~g} /$ $100 \mathrm{ml}$ ), jaundice, and generalized pains. Since then she had only one further admission to hospital with probably a sickle-cell crisis. The patient's obstetric history is even more benign than that in Case 1. Between 1957 and 1971 she had seven successful and uncomplicated pregnancies (two boys and five girls). Delivery of the last child was by caesarean section, at which time she was sterilized.

At the present examination she was $4 \mathrm{ft} 11$ in $(148 \mathrm{~cm})$ tall and weighed $41.3 \mathrm{~kg}$. She had slight cardiomegaly, and the liver extended to 2 to 3 finger-breadths below the costal margin. The spleen was not palpable. Haemoglobin electrophoresis showed Hbs S, F, and $A_{2}$, again with a small trace of $\mathrm{Hb}$ Bart's. Similarly to Case 1 the $\mathrm{Hb} \mathrm{F}$ was heterogeneously distributed among the red cells, some of which contained small inclusion bodies. She was also iron deficient; serum iron $15 \mu \mathrm{g} / 100 \mathrm{ml}$. In this case the mother but not the father was available, and she was a sickle-cell trait carrier. All the children examined were sicklers, but there were three fathers of whom only one (a non-sickler) was examined.

The haematological data of the patients in Cases 1 and 2 and of their parents are summarized in Table I.

Biosynthetic Studies.-The total synthesis of $\alpha$ - and $\beta$ S. chains by the bone marrow precursors of the patients are shown in Table II. The ratio of specific activities of $\alpha: \beta^{S}$ chains were 0.43 and 0.75 respectively, and the ratio of total counts was 0.56 and 0.65 . These ratios contrast to a ratio of $0.99-1 \cdot 15$ found in normal controls, and also to an $\alpha: \beta$ ratio of 0.93 to 1.08 found in eight patients with homozygous sickle-cell disease (White, 1972).

\section{Discussion}

The past histories of the two patients, although essentially characteristic of sickle-cell anaemia, are unusual-especially in respect of the multiple and uncomplicated pregnancies. If this diagnosis is accepted, then an explanation has to be sought. There appears to be at least three possibilities. Firstly, the socioeconomic status of the two patients; secondly, the increased levels of $\mathrm{Hb} \mathrm{F}$; and, thirdly, the presence of $\alpha$-thalassaemia.
TABLE II-Relative Rates of Synthesis of $\alpha$-Chains to $\beta$ S-Chains in Marrow Precursors in Cases 1 and 2

\begin{tabular}{|c|c|c|c|c|c|c|}
\hline \multirow{2}{*}{$\begin{array}{l}\text { Case } \\
\text { No. }\end{array}$} & \multicolumn{2}{|c|}{$\begin{array}{l}\text { Specific Activity } \\
\text { (Counts per } \min / \AA 280 \text { ) }\end{array}$} & \multirow{2}{*}{$\begin{array}{l}\text { Ratio } \\
\alpha: \beta S\end{array}$} & \multicolumn{2}{|c|}{$\begin{array}{l}\text { Total 'H-leucine } \\
\text { Incorporated } \\
\text { (Counts per min) }\end{array}$} & \multirow{2}{*}{$\begin{array}{l}\text { Ratio } \\
\alpha: \beta S\end{array}$} \\
\hline & $\alpha$ & $\beta S$ & & $\alpha$ & $\beta S$ & \\
\hline$\frac{1}{2}$ & $\begin{array}{r}1,023 \\
475\end{array}$ & $\begin{array}{r}2,372 \\
634\end{array}$ & $\begin{array}{l}0.43 \\
0.75\end{array}$ & $\begin{array}{r}22,586 \\
9,102\end{array}$ & $\begin{array}{l}40,689 \\
19,077\end{array}$ & $\begin{array}{l}0.86 \\
0.65\end{array}$ \\
\hline
\end{tabular}

Both patients belonged to an equivalent of "middle-class" in terms of their social status. The husband in Case 1 was a farmer, while the husband in Case 2 was a policeman. Whether or not this could explain their "benign" disease is difficult if not impossible to ascertain, but it is the impression of most authorities that the morbidity and mortality of sickle-cell anaemia decreases with increasing social status of the affected patients. In Ghana this has been borne out by Konotey-Ahulu (1971) in an extensive study at the Sickle-cell Anaemia Clinic in Accra.

The increased levels of $\mathrm{Hb} \mathrm{F}$ in both patients might well modify the clinical picture. This association was first noted by Jackson et al. (1961). Charache and Conley (1964) showed in vitro that $\mathrm{Hb} F$ would increase the solubility of $\mathrm{Hb} S$ at low oxygen tensions, and it was pointed out by Apthorp et al. (1963) that the two cases of successful pregnancy in sickle-cell anaemia they described both had raised levels of $\mathrm{Hb} F$ and came from a highly selected socioeconomic group. These factors also apply to the present patients, and there is the additional possibility that the interaction with $\alpha$-thalassaemia may have had a part in modifying the clinical picture.

The diagnosis of $\alpha$-thalassaemia is based on the findings of a deficiency of $\alpha$-chains synthesized by bone marrow precursors. The only other supporting evidence is that both had trace amounts of $\mathrm{Hb}$ Bart's, as did the latest child of the patient in Case 1. Nevertheless, with the degree of deficiency of $\alpha$-chains synthesized observed, it is difficult to entertain an alternative diagnosis. One possible explanation for the discrepancy between the haematological findings and the biosynthetic studies is that the $\alpha$-thalassaemia gene in West Africa results in a milder clinical and haematological picture than that found in Mediterranean or South Asian peoples. Observations by Schwartz and Atwater (1972) on $\alpha$-thalassaemia in American Negroes support this contention. Their haematological findings on 16 patients are summarized in Table III, where it is noteworthy that the levels of $\mathrm{Hb} \mathrm{A}_{2}$ in $\alpha$-thalassaemia trait are all within the normal range. It should be added that a low $\alpha: \beta$ ratio has been observed in iron deficiency, but never less than 0.9 . Moreover, the presence of iron deficiency might well obscure the other haematological features of $\alpha$-thalassaemiathat is, the significant amounts of Hb Bart's.

TABLE III-Haematological Indices of American Negroes Suffering from $\alpha$-Thalassaemia and $\mathrm{Hb} H$ Disease*

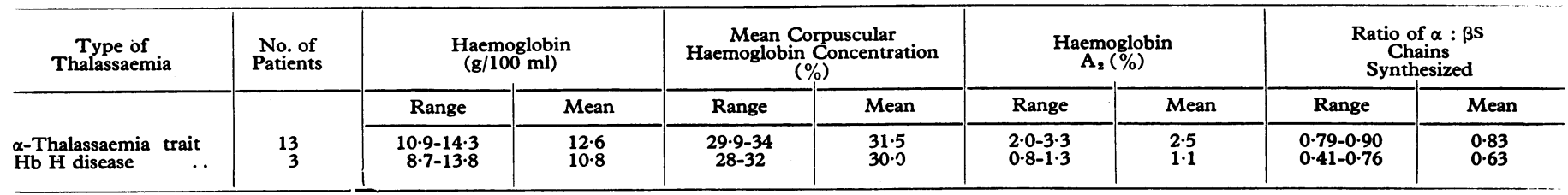

* Data extracted from the studies of Schwartz and Atwater (1972). 
The incidence of the $\alpha$-thalassaemia gene in Africa still remains unsettled. Most studies have used the presence of Hb Bart's in cord blood as the index. Esan (1972) pointed out, however, that in a survey of 1,816 Nigerian cord bloods the presence or absence of $\mathrm{Hb}$ Bart's did not correlate with the haematological features expected in an $\alpha$-thalassaemia. This contrasted with the findings of another large study by Weatherall (1963) who found the incidence was $2 \%$ in 900 cord blood samples of American Negroes, where it was always associated with signs of thalassaemic disorder. Our own observation that trace amounts of $\mathrm{Hb}$ Bart's are a feature of the present patients would support this. Thalassaemia syndromes like $\mathrm{Hb} \mathrm{H}$ disease are rare in Africa, though it has been reported (Barclay et al., 1969) that Bart's hydrops fetalis syndrome has not yet been described. Schwartz and Atwater (1972) conclude that their findings may be due to the benign expression of the $\alpha$-thalassaemia gene in their patients. Certainly their data on the haematological picture of the $\alpha$-thalassaemia trait would make this condition difficult to diagnose without biosynthetic studies.

From our results it also appears that the interaction of $\alpha-$ thalassaemia with homozygous sickle-cell disease does not result in the picture typical of $\alpha$-thalassaemia seen in other ethnic groups, nor, and perhaps more relevant to this study, does the presence of the gene modify the haematological features one would expect with typical homozygous sickle-cell disease, except for the mean corpuscular haemoglobin concentration.

In both patients the mean corpuscular haemoglobin concentration was below normal levels. This single index might provide an explanation for their relatively benign clinical status. May and Huehns (1972) have shown that by artificially lowering the haemoglobin concentrations of cells containing $\mathrm{Hb} \mathrm{S}$, the degree of protein-protein interaction and sickling is lessened. $\alpha$-Thalassaemia gene might have the same effect by lowering in vivo the intracellular haemoglobin concentration.

This is the first time that $\alpha$-thalassaemia has been shown incontrovertibly in West Africa. It seems that biosynthetic studies are required to enable this to be done because the electrophoretic and haematological evidence is minimal. The examination of globin chain synthesis of children born with $\mathrm{Hb}$ Bart's in their cord blood and of their parents might establish the true incidence of $\alpha$-thalassaemia. It will also be important to examine the globin chain synthesis of other sicklecell anaemia patients who show an unusually benign clinical course.

The inclusion bodies in the present patients require some comment. Inclusion bodies were noted in sickle-cell anaemia erythrocytes by Lehmann (1969) who suggested that they might be $\alpha$-chain precipitates and contribute to the shortened life span of the red cells. White (1972) has indeed observed free $\alpha$-chains in biosynthetic experiments on sickle-cell anaemia reticulocytes, but they were not a constant finding either in all patients or at all times in the same patients. Schneider et al. (1972) described inclusion bodies in cells containing $\mathrm{Hb} S$ or $\mathrm{Hb} \mathrm{C}$, and the inclusion bodies seen in the peripheral blood of the two women reported here resembled those described. As they are associated with $\alpha$-thalassaemia it is most unlikely that they are $\alpha$-chain precipitates. On the other hand if ordinary sickle-cell anaemia patients can experience a surplus of $\alpha$-chains even irregularly, $\alpha$-thalassaemia trait would obviously be advantageous to them. But much more work will have to be done on the biosynthesis of $\mathrm{Hb} \mathrm{S}$ in anaemia, other sickle-cell disease states, and the trait, before it will be possible to generalize about the role of $\alpha$-thalassaemia in populations in which sickling is frequent.

\section{References}

Apthorp, G. H., Measday, B., and Lehmann, H. (1963). Lancet, 1, 1344 Barclay, G. P.' T., Charlesworth, D., and Lehmann, H. (1969). British Medical Fournal, 4, 595.

Betke, K., Marti, H. R., and Schlicht, I. (1959). Nature, 184, 1877.

Charache, S., and Conley, C. L. (1964). Blood, 24, 25.

Clegg, J. B., Naughton, M. A., and Weatherall, D. J. (1966). Fournal of Molecular Biology, 19, 91.

Dacie, J. V., and Lewis, S. M. (1968). Practical Haematology, 4th edn. London, Churchill.

Esan, G. S. F. (1972). British fournal of Haematology, 22, 75

Huehns, E. R., Flynn, F. V., Butler, E. A., and Shooter, E. M. (1960). British fournal of Haematology, $6,388$.

Huisman, T. H. J., and Dozy, A. M. (1965). fournal of Chromatography, 19, 160.

Jackson, J. F., Odom, J. L., and Bell, W. N. (1961). Journal of the American Medical Association, 177, 867.

Konotey-Ahulu, F. I. D. (1971). M.D. Thesis, London University.

Kraus, L. M., Miyaji, T., Iuchi, I., and Kraus, A. P. (1966). Biochemistry, 5, 3701 .

Lehmann, H. (1969). Blood, 34, 732.

Lingrel, I. B., and Borsook, H. (1963). Biochemistry, 2, 309.

Marengo-Rowe, A. J. (1965). Journal of Clinical Pathology, 18, 790

May, A., and Huehns, E. R. (1972). In Internationales Symposium, Synthese, Struktur und Funktion des Hämoglobins, Bad Nauheim, 22-24 April 1971, ed. H. Martin and L. Nowicki, p. 279. Munich, Lehmann.

Nierhaus, K., and Betke, K. (1968). Klinische Wochenschrift, 46, 47

Schneider, R. G., Takeda, I., Gustavson, L. P., and Alperin, J. B. (1972). Nature, 235, 88 .

Schwartz, E., and Atwater, J. (1972). fournal of Clinical Investigation, 51,

Serjeant, G. R., Richards, R., Barbor, F. R. H., and Milner, P. F. (1968). British Medical Yournal, 3, 86.

Serjeant, G. R., Ashcroft, K., Serjeant, B. R., and Milner, P. F. (1973). British fournal of Haematology. In press.

Weatherall, D. J. (1963). British fournal of Haematology, 9, 265.

Weatherall, D. J., Clegg, J. B., Blankson, J., and McNeil, S. (1969). British fournal of Haematology, 17, 517.

White, J. M. (1972). Biochimic. In press.

\title{
Procaine in Malignant Hyperpyrexia
}

\author{
R. F. W. MOULDS, M. A. DENBOROUGH
}

British Medical fournal, 1972, 4, 526-528

\section{Summary}

The caffeine contracture of normal human muscle, which has been used as a model for malignant hyperpyrexia, is greatly potentiated by halothane. Prior administration of procaine markedly reduces the halothane-potentiated caffeine contracture, and procaine given at the height of the contracture induces relaxation.

University of Melbourne Department of Medicine, Royal Melbourne Hospital, Victoria, Australia 3050

R. F. W. MOULDS, M.B., B.MED.scI., Research Fellow

M. A. DENBOROUGH, M.D., F.R.A.C.P., Reader in Medicine

\section{Introduction}

Since malignant hyperpyrexia was first reported (Denborough and Lovell, 1960; Denborough et al., 1962) it has become clear 